Research Paper

\title{
Mycotoxin zearalenone exposure impairs genomic stability of swine follicular granulosa cells in vitro
}

\author{
Xue-Lian Liu 1, Rui-Ying Wu 2, Xiao-Feng Sun ${ }^{3}$, Shun-Feng Cheng 1,3, Rui-Qian Zhang 1, Tian-Yu Zhang 1, \\ Xi-Feng Zhang ${ }^{4}$, Yong Zhao ${ }^{1,3}$, Wei Shen ${ }^{1,2,3}$, Lan Li ${ }^{1,3}$ \\ 1. College of Animal Science and Technology, Qingdao Agricultural University, Qingdao 266109, China; \\ 2. Center for Reproductive Medicine, Qingdao Women's and Children's Hospital, Qingdao University, Qingdao 266034, China; \\ 3. College of Life Sciences, Institute of Reproductive Sciences, Qingdao Agricultural University, Qingdao 266109, China; \\ 4. College of Biological and Pharmaceutical Engineering, Wuhan Polytechnic University, Wuhan 430023, China \\ $\triangle$ Corresponding author: Dr. Lan Li E-mail: lilan9600@126.com, Tel: 86-0532-88030246 \\ (C) Ivyspring International Publisher. This is an open access article distributed under the terms of the Creative Commons Attribution (CC BY-NC) license \\ (https://creativecommons.org/licenses/by-nc/4.0/). See http://ivyspring.com/terms for full terms and conditions.
}

Received: 2017.11.17; Accepted: 2017.12.30; Published: 2018.02.12

\begin{abstract}
Zearalenone (ZEA), a metabolite of Fusarium fungi, is commonly found on moldy grains. Because it can competitively combine to estrogen receptor to disrupt estrogenic signaling, it has been reported to have serious adverse effects on animal reproduction systems. In order to explore the genotoxic effects of ZEA exposure on ovarian somatic cells, porcine granulosa cells were exposed to $10 \mu \mathrm{M}$ and $30 \mu \mathrm{M}$ ZEA for 24 or $72 \mathrm{~h}$ in vitro. The results showed that ZEA exposure for $24 \mathrm{~h}$ remarkably reduced the proliferation of porcine granulosa cells in a dose-dependent manner as determined by MTT analysis and flow cytometry. Furthermore, exposure to ZEA for $72 \mathrm{~h}$ induced apoptosis, and RNA sequence analysis also revealed that the expression of apoptosis related genes were altered. RT-qPCR, immunofluorescence and western blot analysis further confirmed the expression of DNA damage and repair related genes ( $\gamma-H 2 A X, B R C A I, R A D 5 I$ and PRKDC) were increased in ZEA exposed granulosa cells. When the estrogen antagonist, tamoxifen, was added with ZEA in the culture medium, the DNA damage and repairment by ZEA returned to normal level. Collectively, these results illustrate that ZEA disrupts genome stability and inhibits growth of porcine granulosa cells via the estrogen receptors which may promote granulosa cell apoptosis when the DNA repair system is not enough to rescue this serious damage.
\end{abstract}

Key words: Zearalenone; Granulosa cells; Genomic stability; DNA damage

\section{Introduction}

Mycotoxin that is mainly produced by Fusarium fungi and widely distributed in the temperate regions of the world [1]. ZEA is generally found in contaminated corn, wheat, oatmeal and other livestock feeds [2, 3]. ZEA has structural similarity with $17 \beta$-estradiol (E2), and has been shown to competitively bind to estrogen receptors (ERs) and exert estrogenic effects in animals [4-8]. Moreover, ZEA has also been shown to be hepatotoxic, haematotoxic, immunotoxic and genotoxic ${ }^{[9]}$.

Due to the estrogenic characteristic ZEA has been considered as a mammalian endocrine disrupter to produce adverse effects on the reproductive system [10,11]. ZEA mainly has the effects on tissues, including the ovary, uterus, mammary glands and testes where the expression of ERs is high [12]. ZEA exposure can lead to malignancies of the uterus, ovary and mammary gland in estrogen-dependent manner [13]. Pre-pubertal Beagle bitches were exposed to low concentration of ZEA $(75 \mu \mathrm{g} / \mathrm{kg}$ body weight (bw)) at 112 days, and the expression of $\beta$-ERs were affected in the ovary [14]. Moreover, ZEA, alpha-zearalenol ( $\alpha$-ZOL) and bate-zearalenol ( $\beta$-ZOL) can affect steroidogenesis in granulosa cells and increase progesterone (P4) level [15]. ZEA and ethinyl estradiol accelerated the vaginal opening and increased uterine weight and antral follicle numbers in the ovary resulting from the increased expression of 
gonadotropin releasing hormone (GnRH) [16]. Furthermore, ZEA and a-ZOL can also inhibit the synthesis and secretion of follicle stimulating hormone $(\mathrm{FSH})$ in pigs through the non-classical estrogen membrane receptor GPR30 [17].

There are a number of examples to show that ZEA increases the oxidative stress in farm animals [9, $13,18,19]$. Our previous studies have shown that ZEA increased the levels of reactive oxygen species (ROS) and repressed the activity and expression of anti-oxidative enzymes in porcine granulosa cells or oocytes at the concentrations from $15 \mu \mathrm{M}$ to $60 \mu \mathrm{M}$ $[4,5]$. Moreover, in post weaned gilts serum alanine aminotransferase, aspartate aminotransferase, $\gamma$-glutamate transferase and alkaline phosphatase concentrations in liver and serum were increased linearly in a ZEA dose dependent manner but activities of glutathione peroxidase and superoxide dismutase and spleen weight were decreased as dietary ZEA increased [20]. In the liver and spleen, it was observed that ZEA exposure induced different effects on oxidative stress and inflammation [21]. When pregnant rats were fed with diets containing ZEA from gestation days (GD) 1 to 7 and then fed with ZEA-free diets until their offspring were weaned, interleukin-8 and glutathione peroxidase (GPx2) were altered in the gastrointestinal tract of offspring [22]. Furthermore, ZEA exposure not only increased lipid peroxidation, but also induced oxidative DNA damage and inhibited DNA and protein syntheses [23-25]. It has been also reported that ROS may be the factor leading to decrease in mitochondrial membrane potential (MMP) and increase in DNA damage when exposed to ZEA [26]. Several reports also suggested that oxidative damage seemed to be an important determinant of ZEA in vitro and in vivo [27, 28]. It was also found vitamin E could alleviate oxidative stress induced by ZEA and restore cell viability of Leydig cells but limit to restore other functions, showing that ROS production was not mainly caused by steroidogenic failure [29].

It is well known that maintenance of genomic stability is critical for the wellbeing of organisms [30]. ZEA exposure can induce DNA double-strand breaks (DSBs) and upregulate the expression of ataxia telangiectasia mutated (ATM) and p53 family genes [31]. The ATM pathway is responsible primarily for DNA-DSBs, ZEA exposure induced oxidative DNA-DSBs and the expression of ATM, and an increase in the concentration of ZEA further increased DNA damage [24, 31]. It has been found that ZEA can arrest the cell cycle at $S$ and G2/M phases to block DNA replication in some somatic cells of the reproductive system [32]. However, it is unknown the influence of ZEA on genomic stability of ovarian granulosa cells which played vital roles during oocytes growth and development. Therefore, the aim of this investigation was to explore ZEA genotoxicity in the ovarian granulosa cells and the underlying mechanisms.

\section{Materials and methods}

\section{Porcine ovaries collection}

The ovaries of adolescent sows were collected from the Pig Production Cooperation of Qingdao Wan $\mathrm{Fu}$ (Qingdao, Shandong, China). The ovaries were saved in saline, maintained at $37^{\circ} \mathrm{C}$, and transported to laboratory within around $2 \mathrm{~h}$. The procedures of animal and tissue handling performed in this study were approved by the Ethics Committee of Qingdao Agricultural University.

\section{Porcine granulosa cell isolation and culture}

Antral follicles with diameter more than $3 \mathrm{~mm}$ were used for porcine granulosa cells collected by a syringe (10 $\mathrm{ml}$ with 18 -gauge needles). The collected granulosa cells were centrifuged at 1,500 rpm for 3 min as previously described [33]. Washing out the blood cells with phosphate-buffered saline (PBS) followed by centrifugation at $1,500 \mathrm{rpm}$ for $3 \mathrm{~min}$. Finally, the granulosa cells were cultured in DMEM high glucose medium (HyClone, SH30022.01, Beijing, China), adding $10 \%$ fetal bovine serum (FBS; Gibco, 10099-141, Australia), $1 \%$ penicillin and streptomycin at $37^{\circ} \mathrm{C}, 5 \% \mathrm{CO}_{2}{ }^{[34]}$.

\section{ZEA treatments}

ZEA (Sigma, Z2125, MO, USA) was dissolved in DMSO at $20 \mathrm{mM}$ concentration and stored at $-20{ }^{\circ} \mathrm{C}$. Granulosa cells were cultured in 96-well plates or 6-well plates at a density of 5,000 cells or $1 \times 10{ }^{5}$ cells per well, respectively. The cells were allowed to grow for $24 \mathrm{~h}$, then the cells were incubated for 24 and $72 \mathrm{~h}$ with $10 \mu \mathrm{M}$ or $30 \mu \mathrm{M}$ ZEA. Control group was treated with DMSO at the same concentration in ZEA-treated groups.

\section{Cell growth assay}

MTT Detection Kit (Solarbio, M8180, Beijing, China) was utilized to detected cells growth. Briefly, after 24 or $72 \mathrm{~h}$ ZEA treatment, medium was removed and $50 \mu \mathrm{l} /$ well MTT solution in blank medium was added to the 96-well plate and incubated for $4 \mathrm{~h}$, and then $150 \mu \mathrm{l}$ DMSO was added to each well and incubated at $37{ }^{\circ} \mathrm{C}$ in the dark for $1 \mathrm{~h}$. Finally, the plates were read at 570 and $630 \mathrm{~nm}$ using Microplate Reader (Bio-Rad, iMark ${ }^{\mathrm{TM}}$, USA).

\section{Flow cytometry analysis of apoptosis}

Granulosa cells were treated with ZEA at $10 \mu \mathrm{M}$ 
and $30 \mu \mathrm{M}$ for $24 \mathrm{~h}$ and $72 \mathrm{~h}$. Then they were collected and washed three times using PBS. Annexin V-FITC/PI kit (Tran, Fa101, Beijing, China) was used to detect apoptosis or necrosis of porcine granulosa cells by flow cytometry referring to the manufacturer's instruction.

\section{Flow cytometry analysis of cell cycle}

According to the basis of DNA content, flow cytometry was used to analyze the cell-cycle distribution. After cultured for 24 and $72 \mathrm{~h}$, granulosa cells were collected and washed two times using PBS. Then cells were fixed in $70 \%$ ethanol for $2 \mathrm{~h}$ followed by centrifugation at $1,500 \mathrm{rpm}$ for $3 \mathrm{~min}$. And cells were stained by PI (BBI, E607306, Shanghai, China) and RNaseA (10 mg/ml, Beyotime, ST572, Nantong, China) for $10 \mathrm{~min}$ in the dark. All groups were collected 10,000 cells, respectively, for each analysis. The cell-cycle profile was analyzed with Flowjo 7.6 software.

\section{RNA-seq analysis and qRT-PCR}

Total RNA was extracted from granulosa cells using an RNAprep pure MicroKit (Aidlab, RN28, Beijing, China). Then total RNA was reverse transcribed into cDNA by cDNA Synthesis Kit (TransGen, AT311-03, Beijing, China). The reaction program was: $25^{\circ} \mathrm{C}$ for $10 \mathrm{~min}, 42^{\circ} \mathrm{C}$ for $15 \mathrm{~min}, 85^{\circ} \mathrm{C}$ $30 \mathrm{~s}$, and $4^{\circ} \mathrm{C}$ for cooling. Then the cDNA library was sequenced at Novogene Co. (Beijing, China). There were 3 independent samples sequenced. The sequencing data obtained with Illumina Hiseq 2000 sequencing system (San Diego, CA, USA) was aligned to reference genome by HISAT2 software. Next SAMTOOLS software were used to convert sam files to bam files and sort bam files. Then HTSeq software were used to count the amount of gene expression. Finally $\mathrm{R}$ Bioconductor/DESeq2 was applied for plotting differential and abundance expression results from HTSeq. The R Bioconductor/ clusterProfiler was applied for GO and KEGG enrich analysis. The bioinformatic analysis has been previously described [35-39].

RT-qPCR reaction was carried out on LC480 (Roche, Germany). A $20 \mu \mathrm{l}$ reaction solution containing $0.8 \mu \mathrm{l}$ of primers $(20 \mu \mathrm{M}), 2 \mu \mathrm{l}$ cDNA, $10 \mu \mathrm{l}$ of SYBR green, and $7.2 \mu \mathrm{l}$ of nuclease-free water. The PCR reaction was $95^{\circ} \mathrm{C}$ for $10 \mathrm{~min}, 35$ cycles at $95^{\circ} \mathrm{C}$ for $10 \mathrm{~s}$, annealing at $60^{\circ} \mathrm{C}$ for $30 \mathrm{~s}$. GAPGH was used as reference and the expression was analyzed by the formula 2 - (target gene $\mathrm{CT}$ value -reference gene $\mathrm{CT}$. All the primers that used in this study were provided in Table S1.

\section{Immunofluorescent staining}

After treatment, the granulosa cells were fixed in $4 \%$ paraformaldehyde at $4{ }^{\circ} \mathrm{C}$ for $1 \mathrm{~h}$, and permeated with $1 \%(\mathrm{~V} / \mathrm{V})$ Triton $\mathrm{X}-100$ for $20 \mathrm{~min}$ at $37^{\circ} \mathrm{C}$. After washed with PBS, the samples were blocked with 10 $\%$ goat serum dissolved in PBST for $1 \mathrm{~h}$, then incubated with anti- $\gamma-\mathrm{H} 2 \mathrm{AX} \quad(1: 100$ dilution, Bioworld, BS4760, Nanjing, China); anti-BRCA1 (BBI, 20321); anti-RAD51 (BBI, D262104) overnight at $4{ }^{\circ} \mathrm{C}$. After washed with $1 \%$ BSA in PBS three times, the samples were labeled with CY3-conjugated goat anti-Rabbit IgG (H+I) (Beyotime, A0521) for $1 \mathrm{~h}$ at $37^{\circ} \mathrm{C}$. Finally, it was stained for 5 min with Hoechst 33342, washed with PBS and examined under Olympus fluorescence microscope (BX51, Japan). Counting full positive cells of 5 different regions, then positive cells than in the total cells. Finally taking the average of 5 different regions.

Using the results of the immunofluorescent staining, defined a region of interest (ROI) by Image J software (v.1.47) to determine the average fluorescence intensity per unit area. We compared the average intensities between ZEA treated and control cells by using the average values of 5 different regions.

\section{Western blotting}

Western blotting analysis was followed the standard methods [40,41]. The proteins were separated by SDS-PAGE and were transferred onto PVDF membranes. Then the membranes were blocked with $5 \%$ BSA for $1 \mathrm{~h}$, and then were incubated with primary antibodies: anti-GAPDH (ImmunoWay, YM3040, USA), anti-RAD51 (BBI, D262104), anti-XRCC4 (BBI, D151845), anti-TP53 (BBI, D120082), anti-RPA2 (BBI, D123054), anti-USP1 (BBI, D123511), anti-CCND1 (BBI, D220509), anti-ACTIN (Abcam, ab8226, USA) at the concentration of $1.0 \mu \mathrm{g} / \mathrm{ml}$ overnight at $4{ }^{\circ} \mathrm{C}$. Then after washing three times in TBST (Tris-buffered saline, pH 7.4, containing $0.05 \%$ Tween-20), the membranes were incubated at room temperature for $1 \mathrm{~h}$ with secondary antibodies (HRP conjugated goat anti - rabbit lgG $(\mathrm{H}+\mathrm{L})$; BBI, D0216) or (HRP-conjugated goat anti-mouse $\operatorname{lgG}(\mathrm{H}+\mathrm{L})$; Beyotime, A0216) at a dilution of 1:2000 in TBST. Actin/GAPDH was used as internal controls and the data were analyzed by using IPWIN software.

\section{Statistical methods}

Each set of experiments were repeated at least three times, and data were represented as mean \pm SD. Significance between groups was statistically analyzed via one-way analysis of variance (ANOVA) followed by the Tukey's test for multiple comparisons using Graph-Pad Prism analysis software. Results were considered statistically significant at $P<0.05\left(^{*}\right)$ and $P<0.01\left({ }^{* *}\right)$. 


\section{Results}

\section{ZEA exposure affected the growth and apoptosis of porcine granulosa cells}

To study the effect of ZEA on the growth of porcine granulosa cells, they were exposed to $10 \mu \mathrm{M}$ or $30 \mu \mathrm{M}$ ZEA and cultured in vitro for $24 \mathrm{~h}$ and $72 \mathrm{~h}$ (Figure 1A). MTT analysis showed that granulosa cell growth was significantly decreased following $30 \mu \mathrm{M}$ ZEA exposure for $24 \mathrm{~h}$ and $72 \mathrm{~h}(P<0.05$ or $P<0.01)$, compared with that in the control group (Figure 1B). Cell cycles profiles of the granulosa cells were also changed following ZEA exposure for $24 \mathrm{~h}$ and $72 \mathrm{~h}$, particularly for $72 \mathrm{~h}$ (Figure 1C).

Furthermore, the percentages of apoptotic granulosa cells was significantly increased following ZEA exposure for $72 \mathrm{~h}(10 \mu \mathrm{M}, 12.29 \% \pm 0.01 ; 30 \mu \mathrm{M}$, $44.09 \% \pm 0.02)$ compared with the control group $(6.38$ $\% \pm 0.01$; Figure 2A-B). However, there was no significant difference between ZEA exposure and control group for $24 \mathrm{~h}$.

\section{ZEA exposure disturbed gene expression by RNA-seq analysis}

To study the effects of ZEA on gene expression of granulosa cell and investigate the mechanism of granulosa cell apoptosis, RNA-seq was performed. With FDR-the False discovery rate at $<0.1,11,825$ genes were identified including 263 differentially expressed genes (DEGs) between the control group and $10 \mu \mathrm{M}$ ZEA-treated group, 1,904 DEGs between the control group and $30 \mu \mathrm{M}$ ZEA-treated group, and 1,839 DEGs between $30 \mu \mathrm{M}$ and $10 \mu \mathrm{M}$ ZEA-treated groups (Figure $3 \mathrm{~A}$ ), and a heat map was obtained for these DEGs (Figure 3B). After analyzing using principal components analysis (PCA), Figure 3C showed three repeats of different genes from RNA-seq data of control group and ZEA-treated group. Then the DEGs were analyzed by GO-enriched and the results showed that there were a great number of enriched genes in mitotic cell cycle checkpoint, cell cycle regulation, apoptosis process regulation, cell proliferation regulation and phosphorylation regulation (Figure 3D and Figure S2). Next, we chose the DEGs and its degree of difference were greater than 20 fold from the control vs ZEA-treated groups. The DEGs between the control and $30 \mu \mathrm{M}$ ZEA-treated group were enriched in the nuclear factor-kappa B (NF-kB) pathway (Figure 3E).
A

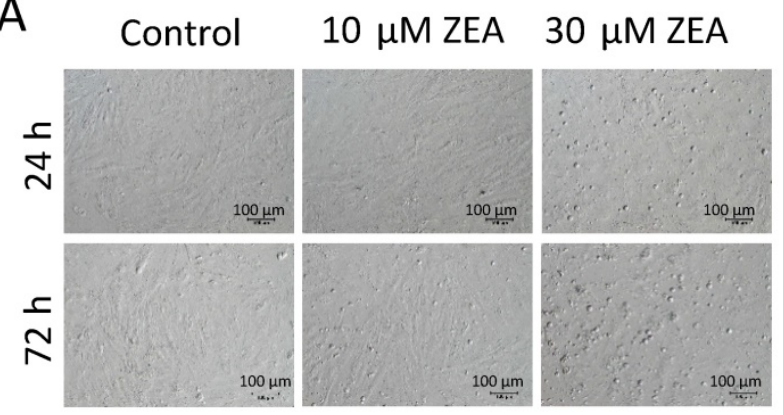

B

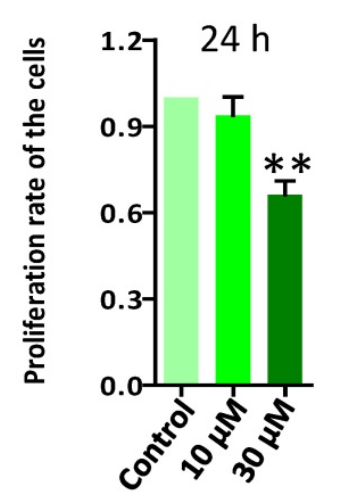

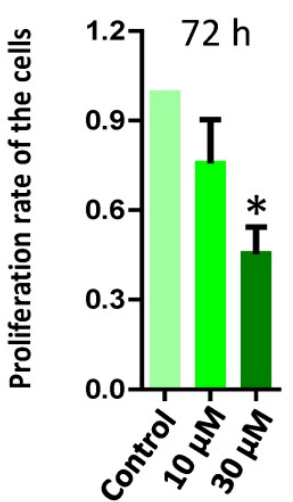
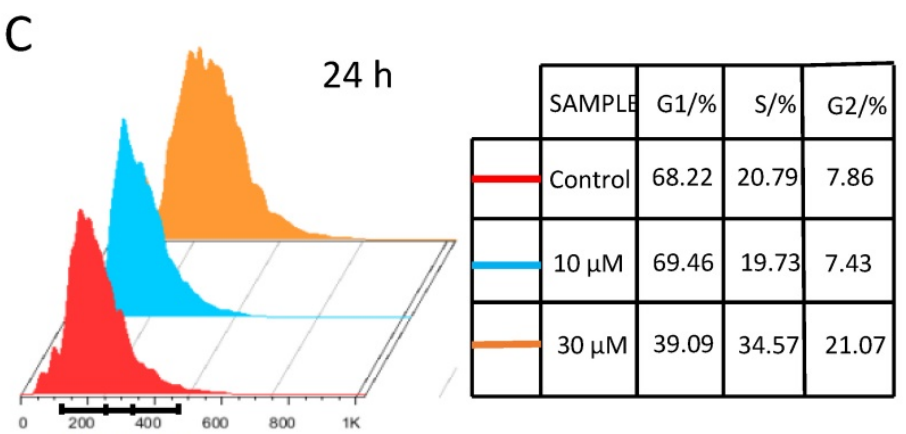

G1 S G2

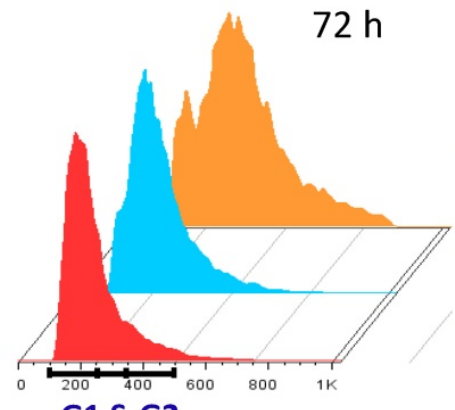

\begin{tabular}{|c|c|c|c|}
\hline SAMPLE & $\mathrm{G} 1 / \%$ & $\mathrm{~S} / \%$ & $\mathrm{G} 2 / \%$ \\
\hline Control & 62.19 & 25.08 & 9.00 \\
\hline $10 \mu \mathrm{M}$ & 41.57 & 39.65 & 14.64 \\
\hline $30 \mu \mathrm{M}$ & 19.36 & 35.04 & 37.12 \\
\hline
\end{tabular}

G1 S G2

Figure 1 Effect of ZEA on the proliferation of procine granulosa cells in vitro. The procine granulosa cells were cultured in vitro and treated with $0 \mu \mathrm{M}, 10 \mu \mathrm{M}$ and 30 $\mu \mathrm{M}$ of ZEA for $24 \mathrm{~h}$ or $72 \mathrm{~h}$. (A) The morphology of porcine granulosa cells exposed to ZEA for $24 \mathrm{~h}$ or $72 \mathrm{~h}$. (B) Cell viability was analyzed by the MTT assay that was used to measure the absorbance of porcine granulosa cells at $570 \mathrm{~nm}$ and $630 \mathrm{~nm}$. The cell viability of porcine granulosa cells between the control group and

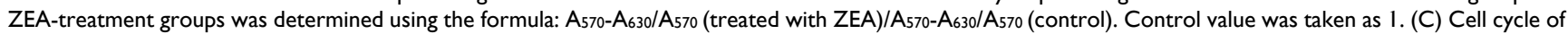
procine granulosa cells was determined by flow cytometer after propidium iodide $(\mathrm{PI})$ staining. Compared to the control group, $*$ indicates significant differences $(P$ $<0.05)$, ${ }^{* *}$ indicated extremely significant differences $(P<0.01)$. All experiments were repeated at least three times. 

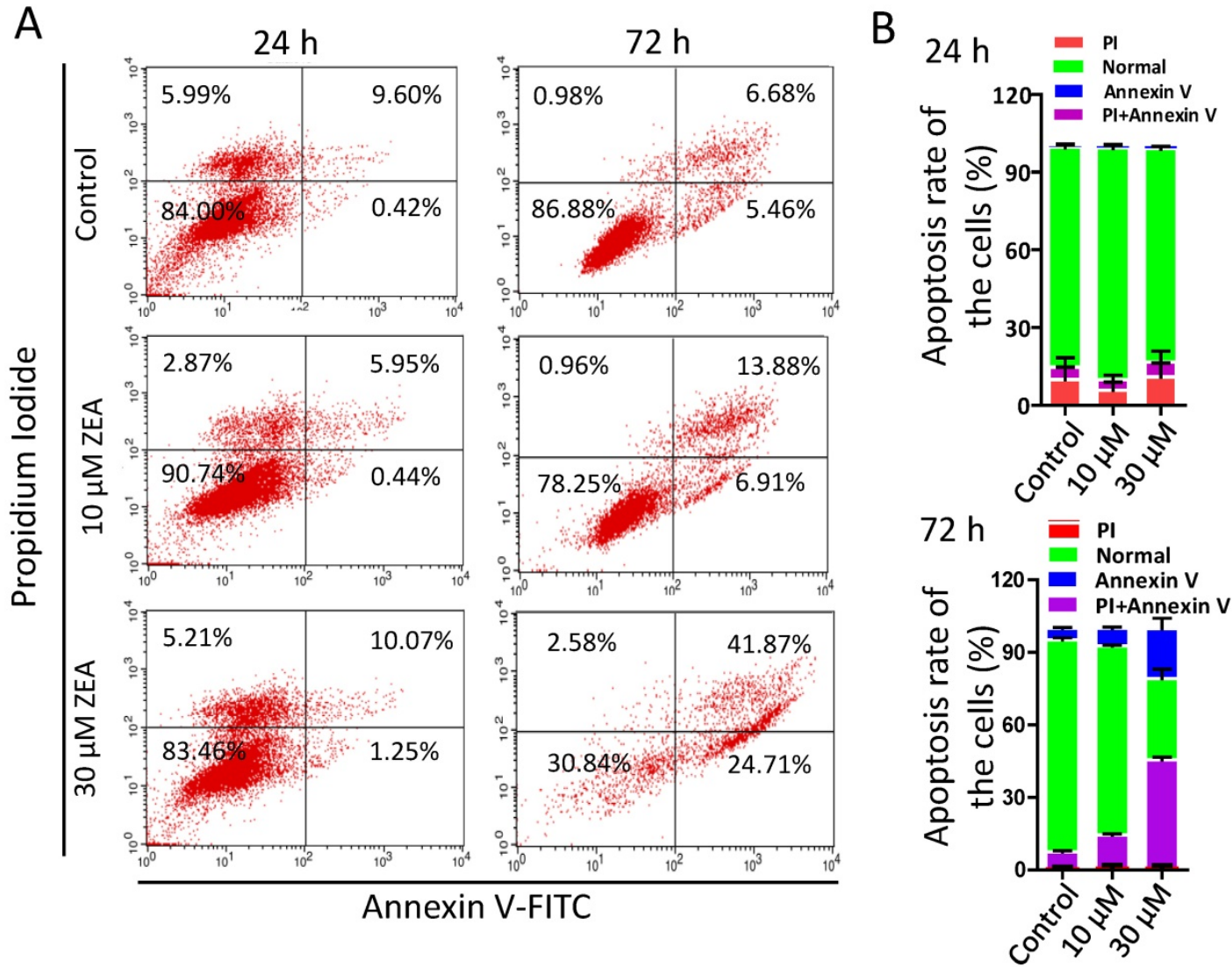

Figure 2 ZEA-induced apoptosis in porcine granulosa cells. (A) Porcine granulosa cells were cultured in the presence of ZEA (10 $\mu \mathrm{M}$ and $30 \mu \mathrm{M})$ for $24 \mathrm{~h}$ or $72 \mathrm{~h}$ and stained with Annexin $\vee$ and Propidium. Cell apoptosis levels were determined using flow cytometry. (B) the apoptotic and necrotic percentages of porcine granulosa cells were analyzed acording to the results of flow cytometry. All experiments were repeated at least three times.

\section{ZEA exposure impaired the genomic stability of granulosa cells}

To further verify ZEA exposure disrupted the signaling pathways from GO-enriched analysis, 10 genes were selected and quantified by RT-qPCR. ZEA exposure significantly up-regulated the mRNA expression of DNA damage repair related genes, such as BRCA1, RAD51 and PRKDC, and strikingly decreased 53BP1, an apoptosis and cell cycle checkpoint related gene $(P<0.01$; Figure 4$)$. However, there was no significantly different expression of $A T R$, ATM, CHEK1, CHEK2, MRE11A and XRCC6. The result of the qRT-PCR was consistent with the date of the RNA-seq. Furthermore, the protein expression levels of XRCC4, TP53, USP1, RPA2 and CCND1 were significantly reduced, but RAD51 was significantly up-regulated, in the ZEA-treated groups compared with that in the control groups $(P<0.05$ or $P<0.01$; Figure 5).

To further determine whether ZEA exposure caused DNA damage, we analyzed the percentage of $\mathrm{\gamma}$-H2AX positive cells following ZEA treatment for 24 $\mathrm{h}$ (Figure 6A). The percentage of $\mathrm{\gamma}-\mathrm{H} 2 \mathrm{AX}$ positive cells was significantly increased in the $10 \mu \mathrm{M}(86.00 \%$ $\pm 0.03)$ and $30 \mu \mathrm{M}$ ZEA treated group $(91.33 \% \pm 0.02)$ compared with that in the control group $(43.33 \% \pm$ 0.06) $(P<0.05$; Figure 6B). Moreover, the fluorescent intensity of $\gamma$-H2AX positive cells in $30 \mu \mathrm{M}$ ZEA treatment was also remarkably increased by 1.44 fold compared with that in the control group $(P<0.05$; Figure 6C).

The percentages of RAD51 positive cells was significantly increased in the $10 \mu \mathrm{M}(54.25 \% \pm 0.09)$ and $30 \mu \mathrm{M}$ ZEA treated group $(59.63 \% \pm 0.02)$ compared with that in the control group $(24.70 \% \pm$ 0.06) $(P<0.01$; Figure 7A, 7B). Furthermore, the fluorescent intensity of RAD51 positive cells in $30 \mu \mathrm{M}$ ZEA treatment was also significantly increased about 2.05 fold compared with that in the control group $(P<$ 0.05) (Figure 7C).

Finally, there was a significant increase in the percentage of BRCA1 positive cells exposed to $10 \mu \mathrm{M}$ or $30 \mu \mathrm{M}$ ZEA for $24 \mathrm{~h}(P<0.05$ or $P<0.01$; Figure $8 \mathrm{~A}$, $8 \mathrm{~B})$, and the fluorescent intensity of BRCA1positive cells was strikingly increased by 1.55 fold and 1.92 fold in $10 \mu \mathrm{M}$ and $30 \mu \mathrm{M}$ ZEA treated groups compared with that of the control group $(P<0.05$ or $P$ $<0.01$; Figure 8C). 


\section{Estrogen receptor antagonist decreased the effects of ZEA on the genomic stability of granulosa cells}

In order to explore the disruption in genomic stability in granulosa cells by ZEA via ER pathway, porcine granulosa cells were exposed to ZEA and ER antagonist tamoxifen for $72 \mathrm{~h}$. There were no significant differences in the protein levels of DNA damage or repairment related genes RAD51, USP1, XRCC1 and RPA2 between the control group and the ZEA and tamoxifen groups (Figure 9).
A

$30 \mu \mathrm{M}$ VS $10 \mu \mathrm{M} \quad 10 \mu \mathrm{M}$ VS Control

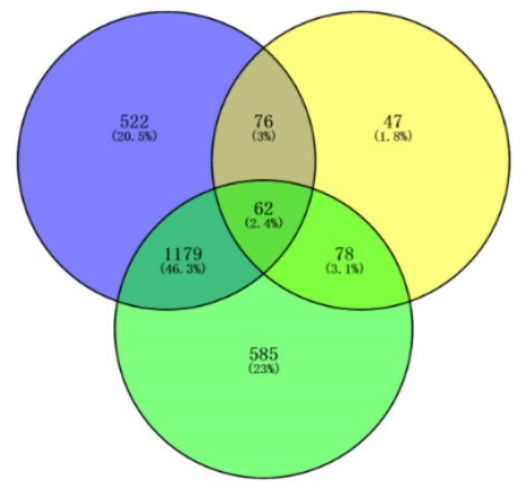

C
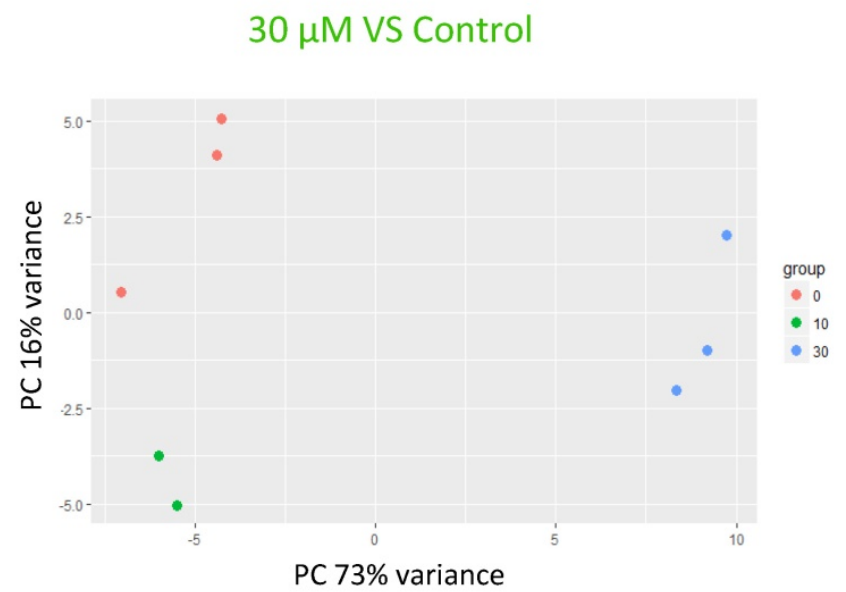

D

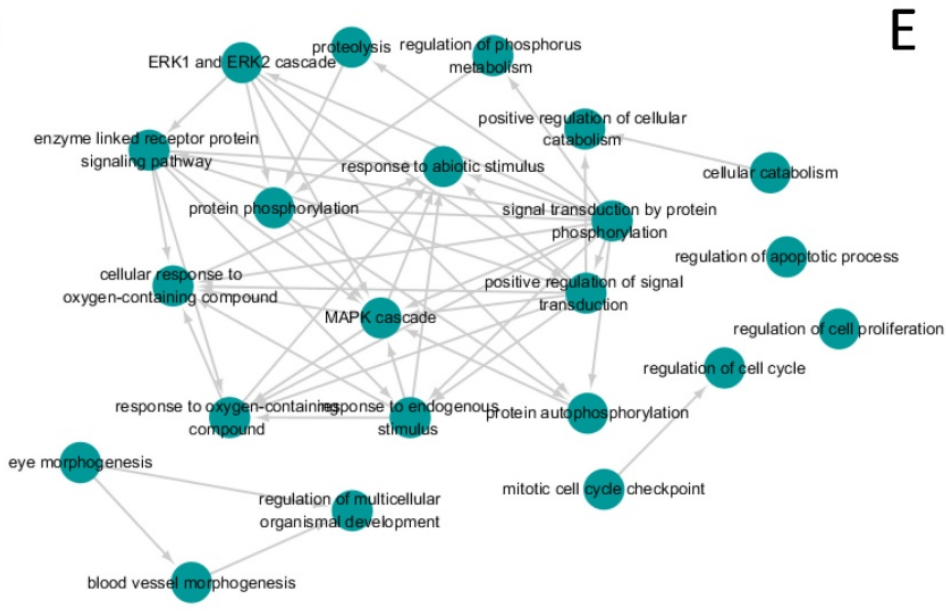

B

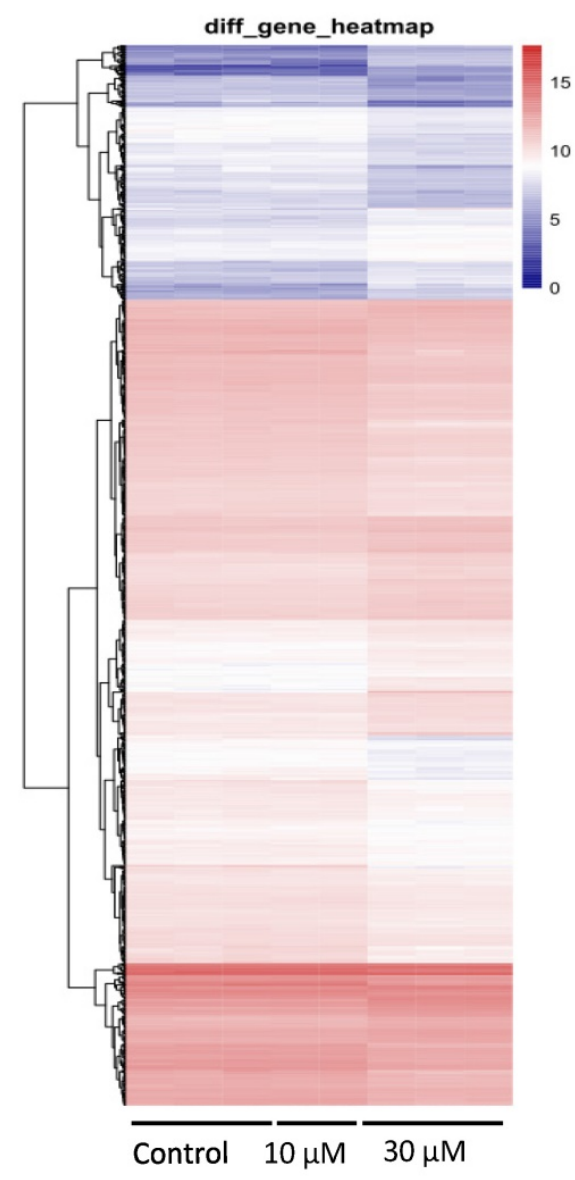

E

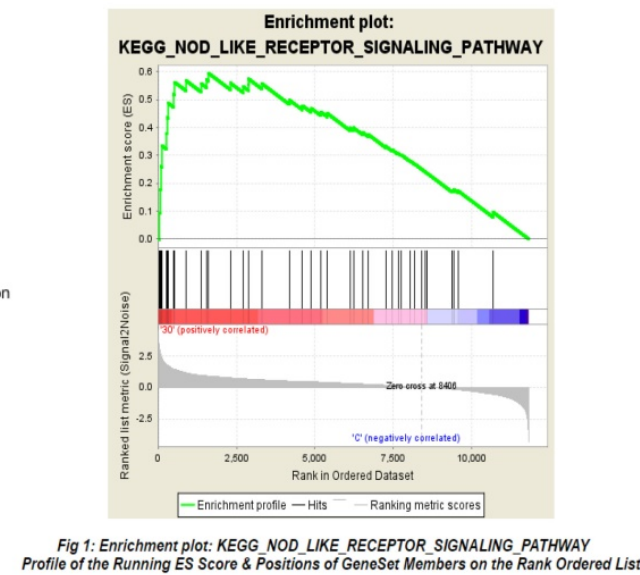

Figure 3 RNA-seq analysis of granulosa cells in control and ZEA-treated groups. (A) Venn diagram demonstrating the different expression of genes between the control group and ZEA-treated groups. (B) Heatmap indicating the group differences of differentially expressed genes (DEGs) between the control group and the ZEA-treated groups, and the repeatability within each group. (C) principal components analysis (PCA) analysis. The 8 samples were shown in the $2 \mathrm{D}$ plane splanned by the first three principal components. (D) Scattergram of Gene Ontology (GO) enrich in biological process categories. (E) Different genes of the control group and the $30 \mu M$ ZEA-treated group enriched in the NF-kB pathway via Gene Set Enrichment Analysis (GSEA). 


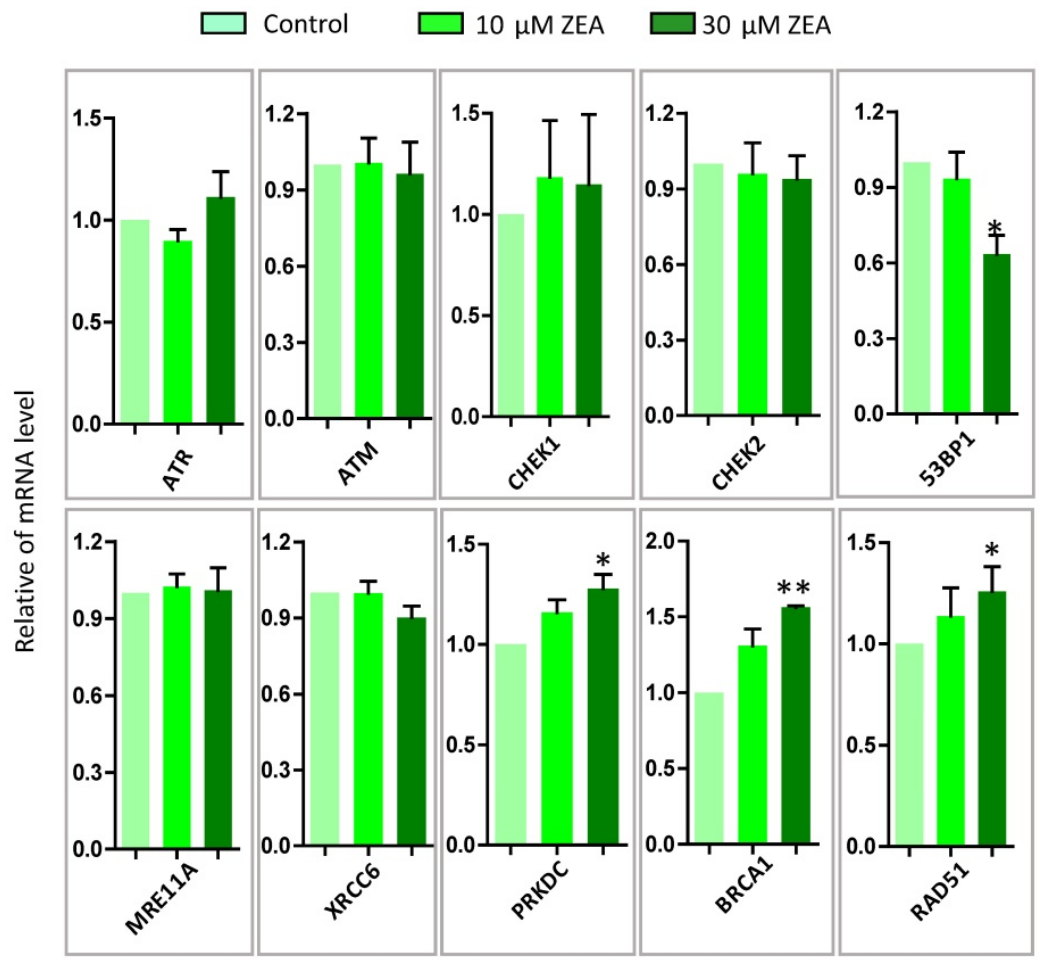

$(\mathrm{N}=6)$

Figure 4 The mRNA expression of genes in granulosa cells in response to ZEA exposure (10 $\mu \mathrm{M}$ and $30 \mu \mathrm{M})$ in porcine granulosa cells for $24 \mathrm{~h}$. The genes of ATM, ATR, CHEKI, CHEK2, P53, XRCC6, MREIIA, PRKDC, RAD5I and BRCAI were measured using RT-qPCR. Compared to the control group, * indicated significant differences $(P<0.05)$, ** indicated extremely significant differences $(P<0.01)$. All experiments were repeated 6 times.
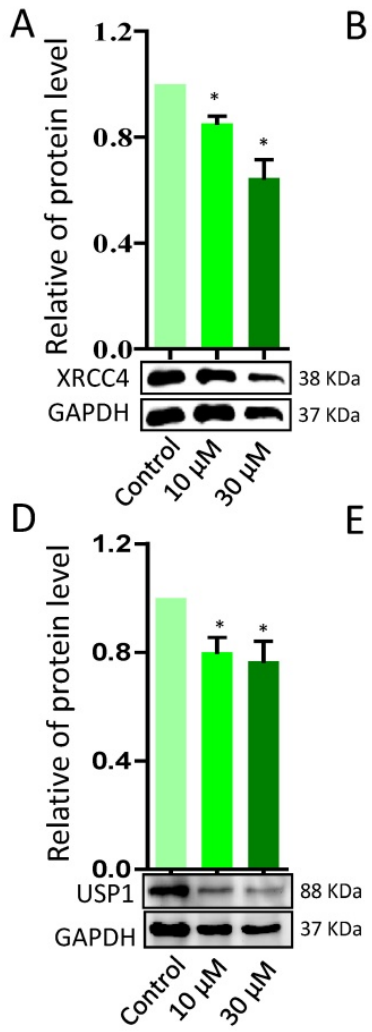

B
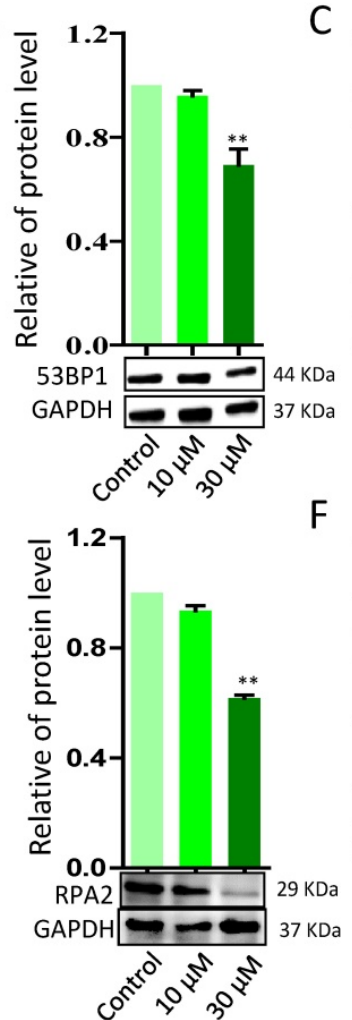

C
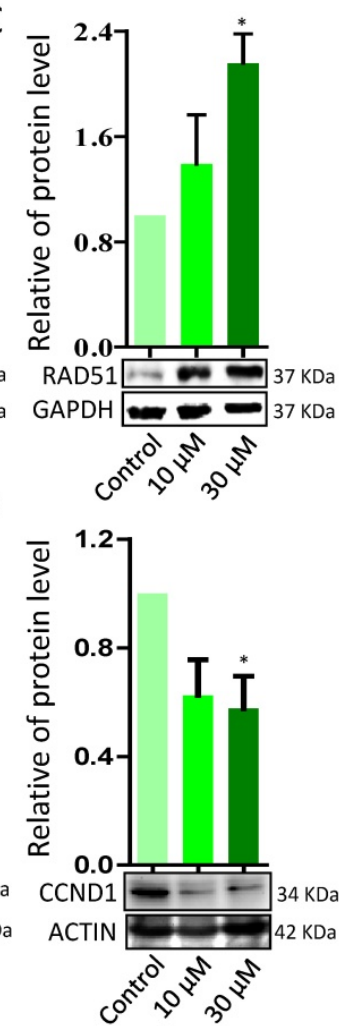

Figure 5 Western blot analysis of the protein expression levels of DNA damage response (DDR) - related proteins in porcine granulosa cells treated with different concentrations of ZEA. GAPDH and ACTIN were used as protein loading controls. ZEA increased RAD51 protein levels while decreasing XRCC4, TP53, USP1, RPA2 and CCND protein levels. Compared to the control group, * indicated significant differences $(P<0.05)$, $* *$ indicated extremely significant differences $(P<0.01)$. All experiments were repeated at least three times. 


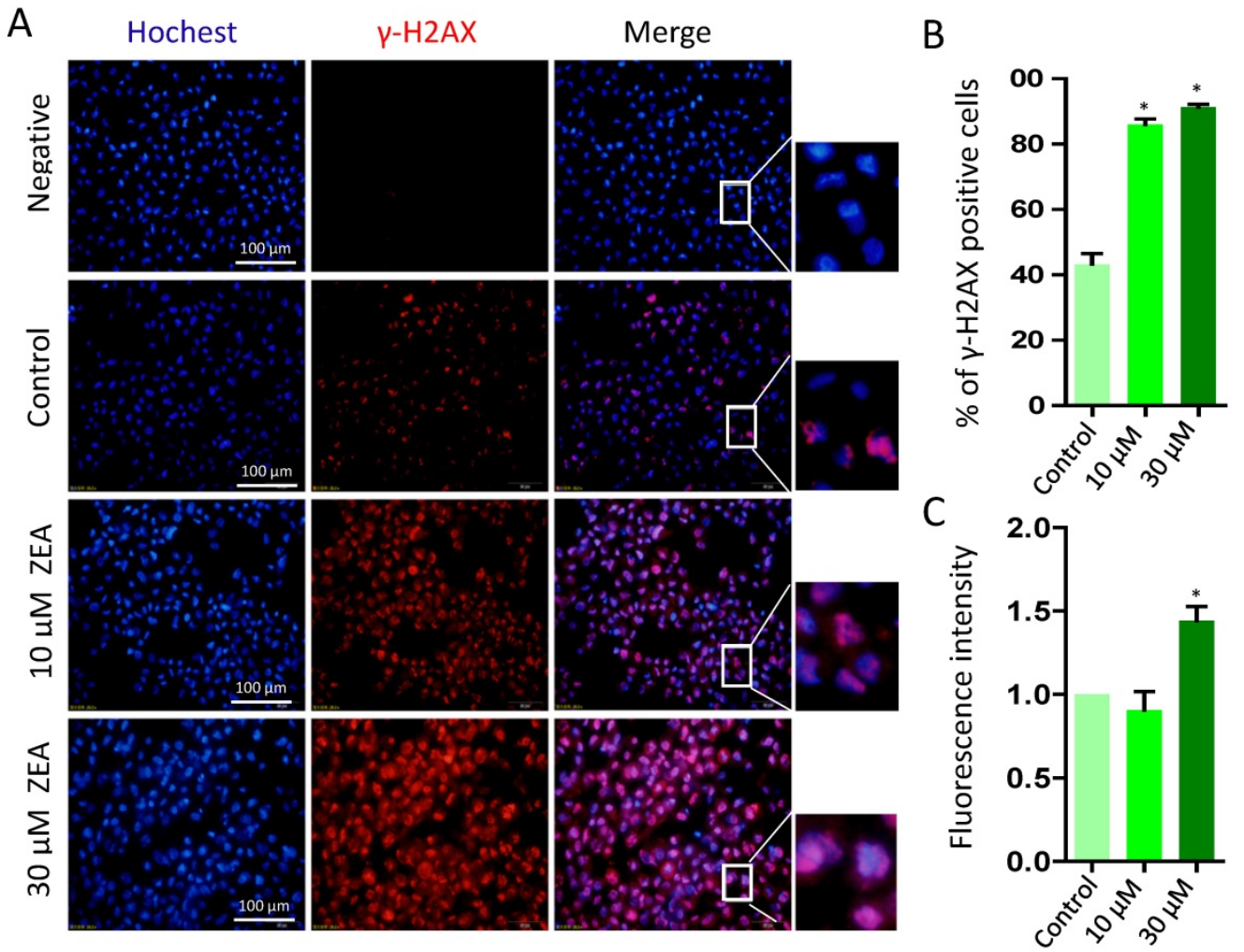

Figure 6 Immunostaining of $\mathrm{Y}-\mathrm{H} 2 \mathrm{AX}$ indicating DNA double strand breaks (DSBs) in porcine granulosa cells. (A) Porcine granulosa cells were treated with ZEA at $10 \mu \mathrm{M}$ and $30 \mu \mathrm{M}$ for $24 \mathrm{~h}$ and stained by indirect immunofluorescence. (B) The result of immunostaining of $\mathrm{Y}-\mathrm{H} 2 \mathrm{AX}$ was observed using fluorescence microscopy. The number of positive cells with $\mathrm{CY} 3-\mathrm{Y}-\mathrm{H} 2 \mathrm{AX}$ was displayed as a histogram. (C) The fluorescence intensity of $\mathrm{Y}-\mathrm{H} 2 \mathrm{AX}$ positive cells was analyzed using Image J. Compared to the control group, $*$ indicated significant differences $(P<0.05)$. All experiments were repeated at least three times.
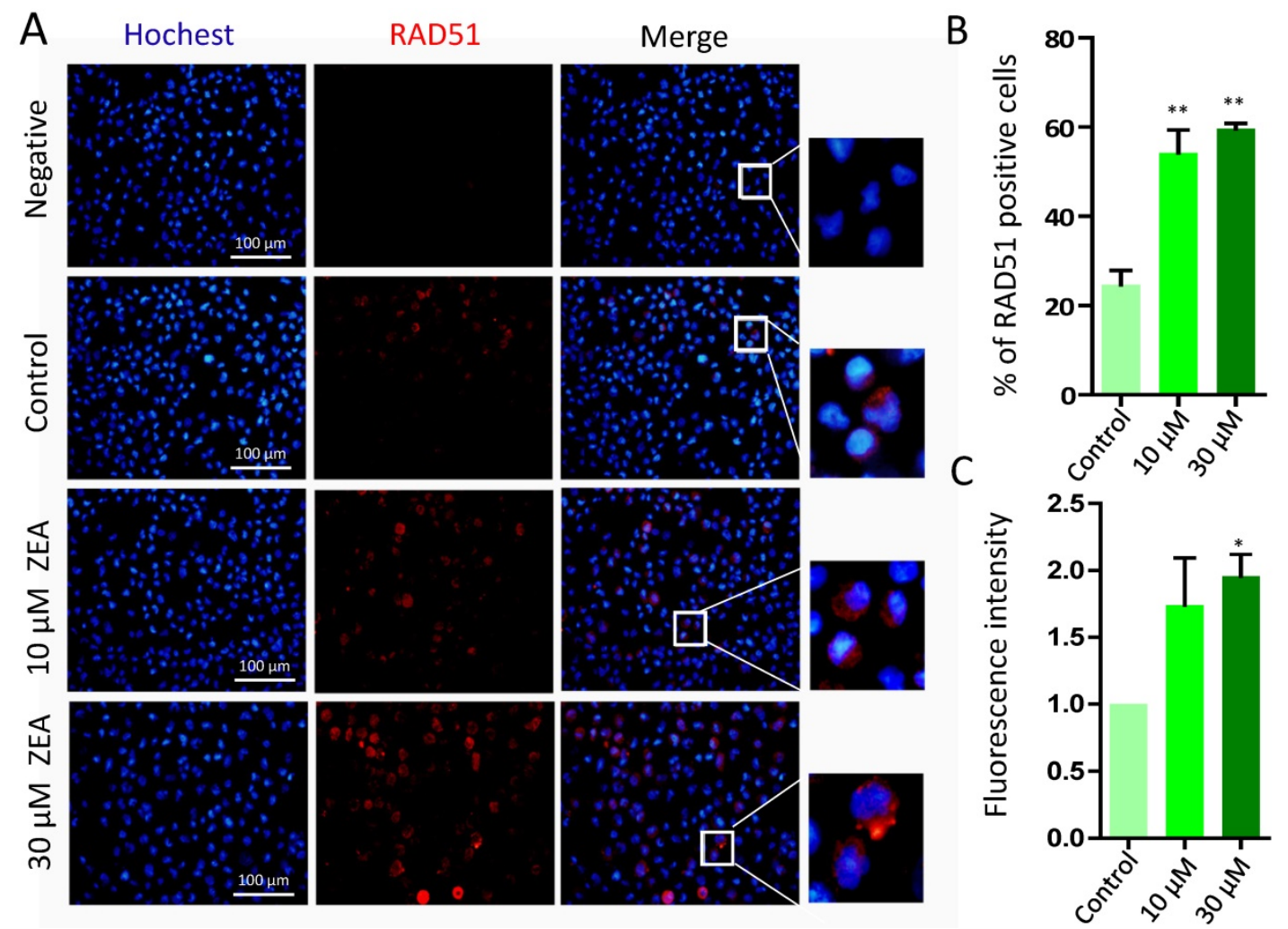

Figure 7 Immunostaining of RAD51 indicating DSBs in porcine granulosa cells. (A) Porcine granulosa cells were treated with ZEA at $10 \mu \mathrm{M}$ and $30 \mu \mathrm{M}$ for $24 \mathrm{~h}$ and stained by indirect immunofluorescence. (B) The result of immunostaining for RAD51 was observed using fluorescence microscopy. The number of positive cells with CY3- RAD51 was displayed as a histogram. (C) The fluorescence intensity of RAD51 positive cells was analyzed using Image J. Compared to the control group, * indicated significant differences $(P<0.05)$, ** indicated extremely significant differences $(P<0.01)$. All experiments were repeated at least three times. 
A Hochest
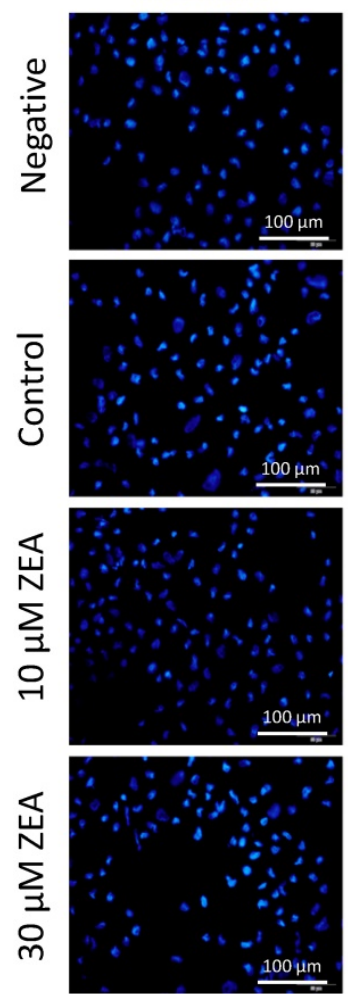

BRCA1
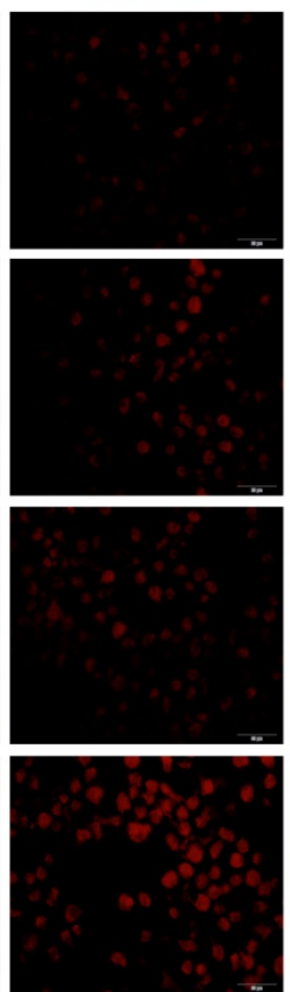

Merge
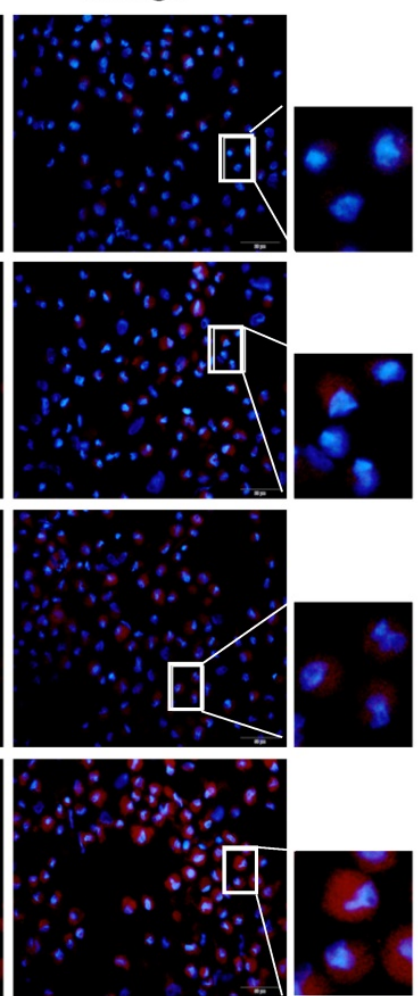
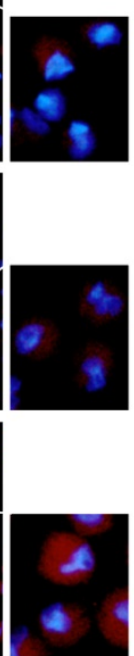

B

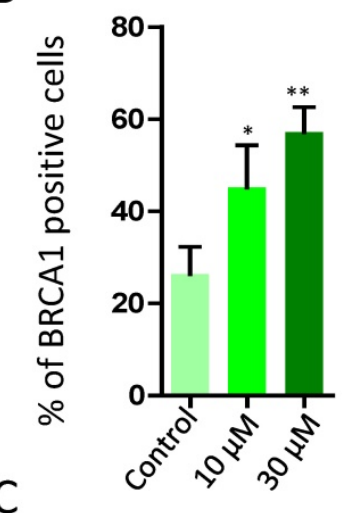

C

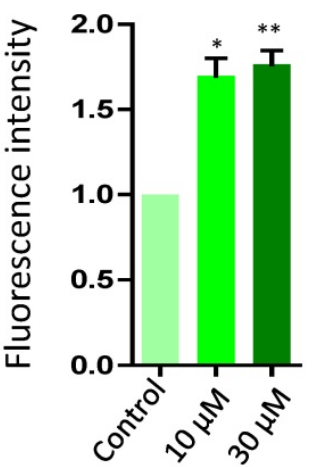

Figure 8 Immunostaining of BRCA1 indicating DSBs in porcine granulosa cells. (A) Porcine granulosa cells were treated with ZEA at $10 \mu \mathrm{M}$ and $30 \mu \mathrm{M}$ for $24 \mathrm{~h}$ and stained by indirect immunofluorescence. (B) The result of immunostaining of BRCAl was observed using fluorescence microscopy. The number of positive cells with CY3- BRCA1 was displayed as a histogram. (C) The fluorescence intensity of BRCA1 positive cells was analyzed using Image J. Compared to the control group, * indicated significant differences $(P<0.05)$, *** indicated extremely significant differences $(P<0.01)$. All experiments were repeated at least three times.

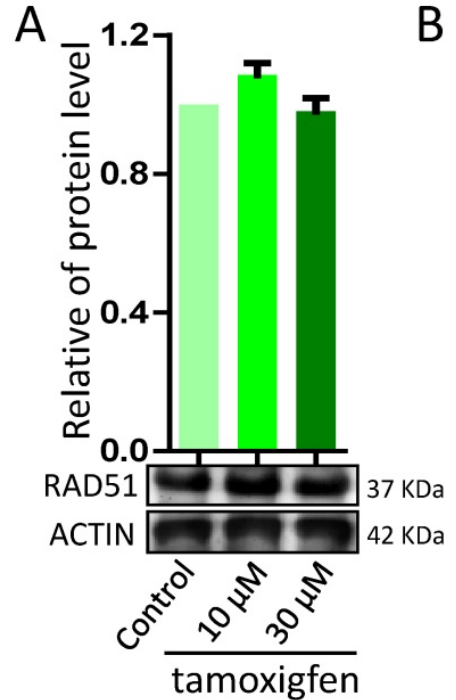

Figure 9 Effect of the estrogen recepter antagonist, Tamoxifen, on DDR in porcine granulosa cells treated with different concentrations of ZEA (10 $\mu M$ and $30 \mu M$ ) for $24 \mathrm{~h}$. Western blot analysis of the expression levels of DDR-related proteins (RAD51, USP1, XRCC4 and RPA2). ACTIN was used as a protein loading control. All experiments were repeated at least three times.

\section{Discussion}

ZEA is a toxic metabolite of Fusarium and commonly found in several food commodities world-
C

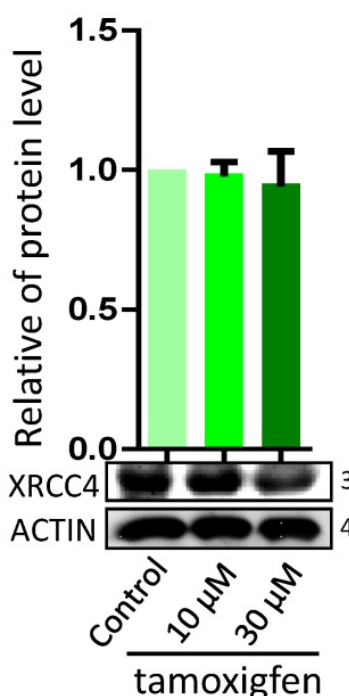

D

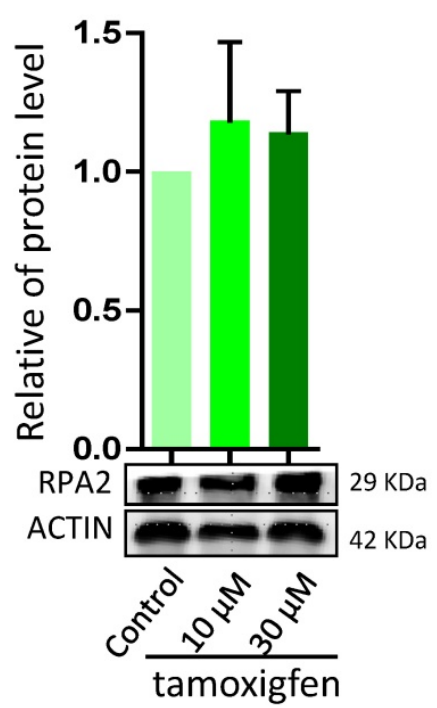


fluid $[15,42]$. A set of experiments demonstrated that ZEA produced several genotoxic effects, such as DNA fragmentation, micronuclei and chromosome aberrations including DNA strand breaks [30,43-46]. Therefore, the genotoxic effects by ZEA in porcine granulosa cells might adversely affect the development of animal ovarian follicles.

Our results demonstrated that ZEA dramatically decreased the growth of porcine granulosa cells in a dose and time dependent manner, and caused a significant increase in apoptotic cells. It was of note that in a previous report from other groups, ZEA exposure led to apoptosis in porcine splenic lymphocytes, immortalized goat Leydig cells, and endometrial stromal cells $[32,47,48]$. Next, ZEA exposure considerably altered the mRNA expression of genes in the granulosa cells using an RNA-seq approach, and the DEGs were found to be involved in cellular processes, molecular functions, and biological processes that were closely associated with cell proliferation, cell cycle, apoptosis, and DNA damage repair. The results collectively suggested that ZEA was genotoxic for porcine granulosa cells in vitro.

In order to protect genomic stability from exogenous and endogenous DNA damaging agents [30], eukaryotic cells have evolved elaborated cell cycle checkpoints and DNA damage response (DDR) systems [49,50]. When DNA damage, mutations or other abnormal conditions occur, the cell cycle checkpoint can timely block or delay cell cycle progression to repair the damaged DNA or regulate cell apoptosis [51, 52]. Cell cycle checkpoints can be divided into three types according to their different functions, such as DNA replication checkpoints, DNA damage checkpoints and spindle assembly checkpoints [53-55]. When cells are challenged with genotoxic stress, the ATM/ATR family of kinases can phosphorylate the histone H2AX. The phosphorylation of $\mathrm{H} 2 \mathrm{AX}(\mathrm{\gamma}-\mathrm{H} 2 \mathrm{AX})$ is thought to recruit MRE11-RND51-NSB1 (MRN) directly to DNA-DSBs, and the $\gamma-\mathrm{H} 2 \mathrm{AX} / \mathrm{MRN}$ complex can recruit other DNA damage signals, such as MDC1 and BRCA1 [56]. Furthermore, the MRN complex, 53BP1 and MDC1 can help ATM phosphorylate CHK2 to induce the cell cycle checkpoint [57]. Also, ATR can directly phosphorylate $\mathrm{CHK} 1$ to impact the cell cycle process [58]. RPA, as a heterotrimeric protein complex, specifically binds to single-stranded DNA assisting in DNA synthesis, and RPAs are required for DNA replication [59-62]. In this study, our results showed that ZEA exposure can increase the gene and protein expression of $\mathrm{\gamma}-\mathrm{H} 2 \mathrm{AX}, \mathrm{RAD} 51$ and BRCA1, however significantly decrease p53 and RPA2 protein expression in granulosa cells (Figure 10).

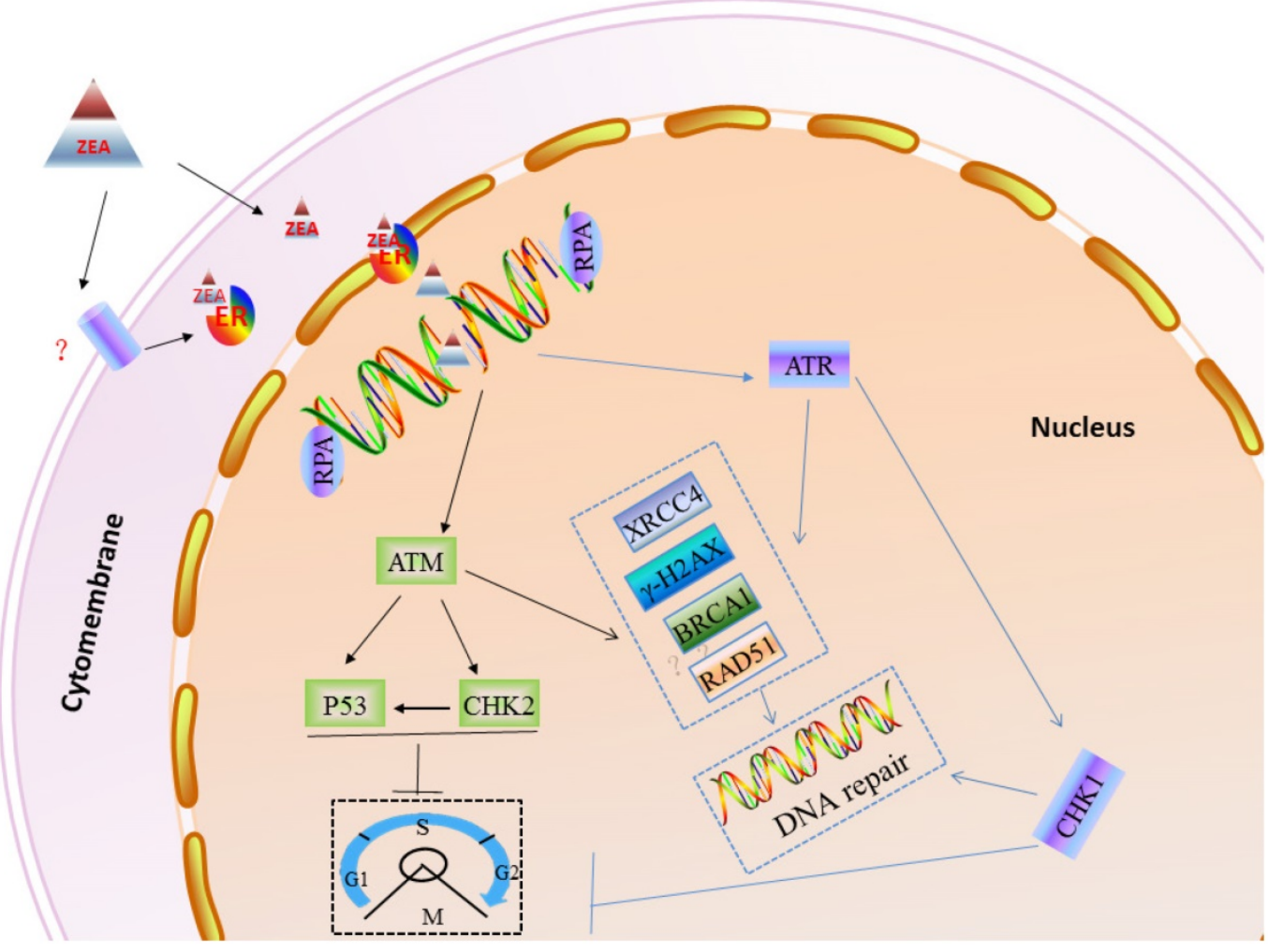

Figure $10 \mathrm{~A}$ working model to inlustrate the role of DDR in ZEA-induced DSBs in porcine granulosa cells. DNA DSBs actived ATR or ATM protein. Subsequently, ATR or ATM induced cell cycle arrest of porcine granulosa allowing enought time to recruit DDR proteins (RAD51, BRCA1, PRKDC etc.) that then repair the damaged DNA. 
It is well known that the DNA repairing pathway includes the non-homologous end joining (NHEJ, e.g. 53BP1, XRCC6 and RIF1) and the homologous recombination (HR, RAD51, BRCA1 and MRE11A) pathways [63, 64]. Some DDR proteins include ATM, ATR and DNA-dependent protein kinases [65]. Some DDR proteins can not only repair DNA lesions but also manage cell cycle checkpoints. NHEJ is active throughout the cell cycle but favored in G1 cells, after DNA replication, HR is more prevalent, because there is an identical and available sister chromatid as a template for repairing [66]. The balance between NHEJ and HR shifts during the cell cycle [67]. The expression level of USP1, the deubiquitinating enzyme, through the APCCdh1 complex can determine which DNA repair pathway, HDR or NHEJ, will be used. When USP1 is degraded by APCCdh1, cells use the HR pathway of DNA repair, and conversely cells would use the NHEJ pathway [68]. In this study, ZEA exposure reduced USP1 and XRCC4 protein levels in granulosa cells, which suggested that ZEA exposure caused DNA lesions and activated the DNA damage checkpoint in the $S$ and $\mathrm{G} 2 / \mathrm{M}$ phases ultimately inducing the HR pathway to repair the damaged DNA. ZEA exposure increased the transcriptional level of ATR and CHEK1 but not MRE11A, XRCC6, $A T M$ and CHEK2, suggesting the impact of ZEA exposure on the cell cycle process or DNA repairing may be at the level of post- transcription and translation modification.

ZEA is a non-steroidal and can competitively bind to ERs affecting the development of ovary in pre-pubertal bitches [15], so we aimed to determine if ZEA exposure could negatively impact the genomic stability of cells through ERs, finally reducing the grow of cells or increasing cellular apoptosis. The results showed that there were not significantly change the expression level of RAD51, USP1, XRCC4 and RPA2 when added with $1 \mu \mathrm{M}$ of the ER antagonist Tamoxifen to the medium in vitro.

In summary, our finding has shown that ZEA, as a DNA damaging agent, can cause DNA-DSBs and influence genome stability in porcine granulosa cells via the ER pathway, further leading to a reduced granulosa cell proliferation rate and arrest cell cycle in the $S$ and G2/M phases. When the DNA repair system is not enough to rescue seriously damaged granulosa cells, it may promote granulosa cell apoptosis (Figure 10).

\section{Supplementary Material}

Supplementary figures and tables. http://www.ijbs.com/v14p0294s1.pdf

\section{Acknowledgements}

This work was supported by National Natural Science Foundation of China (31572225), National Key Research and Development Program of China (2016YFD0501207), and Natural Science Foundation of Hubei Province of China (2016CFC726). We would like to thank Prof. Paul W. Dyce (Auburn University) for his careful editing of the manuscript.

\section{Competing Interests}

The authors have declared that no competing interest exists.

\section{References}

1. Escrivá L, Font G, Manyes L et al. Studies on the presence of mycotoxins in biological samples: an overview. Toxins (Basel). 2017; 9(8): E251.

2. Kuiper-Goodman T, Scott PM, Watanabe H. Risk assessment of the mycotoxin zearalenone. Regulatory Toxicol Pharmacol. 1987; 7: 253-306.

3. Lauren DR, Ringrose MA. Determination of the fate of three Fusarium mycotoxins through wet-milling of maize using an improved HPLC analytical technique. Food Addit Contam. 1997; 14: 435-443.

4. Qin X, Cao M, Lai F et al. Oxidative stress induced by zearalenone in porcine granulosa cells and its rescue by curcumin in vitro. PLoS ONE. 2015; 10: e0127551.

5. Lai F, Ma J, Liu J et al. The influence of N-acetyl-1-cysteine on damage of porcine oocyte exposed to zearalenone in vitro. Toxicol Appl Pharmacol. 2015; 289: 341-348.

6. Liu $\mathrm{K}$, Sun $\mathrm{X}$, Feng $\mathrm{Y}$ et al. The impact of Zearalenone on the meiotic progression and primordial follicle assembly during early oogenesis. Toxicol Appl Pharmacol. 2017; 329: 9-17.

7. Pang J, Zhou Q, Sun X et al. Effect of low-dose zearalenone exposure on reproductive capacity of male mice. Toxicol Appl Pharmacol. 2017; 333: 60-67.

8. Zhang GL, Sun $\mathrm{XF}$, Feng $\mathrm{YZ}$ et al. Zearalenone exposure impairs ovarian primordial follicle formation via down-regulation of Lhx8 expression in vitro. Toxicol Appl Pharmacol. 2017; 317: 33-40.

9. Zinedine A, Soriano JM, Molto JC et al. Review on the toxicity, occurrence, metabolism, detoxification, regulations and intake of zearalenone: an oestrogenic mycotoxin. Food Chem Toxicol. 2007; 45: 1-18.

10. Bovee TF, Helsdingen RJ, Rietjens IM et al. Rapid yeast estrogen bioassays stably expressing human estrogen receptors alpha and beta, and green fluorescent protein: a comparison of different compounds with both receptor types. J Steroid Biochem Mole Biol. 2004; 91: 99-109.

11. Slomczynska M. The effect of phytoestrogens on the reproductive tract. Polish J Vet Sci. 2004; 7: 223-226.

12. Kuiper GG, Lemmen JG, Carlsson B et al. Interaction of estrogenic chemicals and phytoestrogens with estrogen receptor beta. Endocrinology. 1998; 139: 4252-4263.

13. Gajecki M, Przybylowicz M, Zielonka L et al. Preliminary results of monitoring research on zearalenone presence in blood of women with neoplastic lesions in reproductive system. Polish J Vet Sci. 2004; 7: 153-156.

14. Gajecka M. The effect of low-dose experimental zearalenone intoxication on the immunoexpression of estrogen receptors in the ovaries of pre-pubertal bitches. Polish J Vet Sci. 2012; 15: 685-691.

15. Gajecka M, Zielonka L, Gajecki M. The effect of low monotonic doses of zearalenone on selected reproductive tissues in pre-pubertal female dogs--a review. Molecules. 2015; 20: 20669-20687.

16. Kriszt R, Winkler Z, Polyak A et al. Xenoestrogens ethinyl estradiol and zearalenone cause precocious puberty in female rats via central kisspeptin signaling. Endocrinology. 2015; 156: 3996-4007.

17. He J, Wei C, Li Y et al. Zearalenone and alpha-zearalenol inhibit the synthesis and secretion of pig follicle stimulating hormone via the non-classical estrogen membrane receptor GPR30. Mol Cell Endocrinol. 2018; 461:43-54

18. Zwierzchowski W, Przybylowicz M, Obremski K et al. Level of zearalenone in blood serum and lesions in ovarian follicles of sexually immature gilts in the course of zearalenone micotoxicosis. Polish J Vet Sci. 2005; 8: 209-218.

19. Gonzalez Pereyra ML, Pereyra CM et al. Determination of mycobiota and mycotoxins in pig feed in central Argentina. Letters Appl Microbiol. 2008; 46: 555-561.

20. Jiang SZ, Yang ZB, Yang WR et al. Effects of purified zearalenone on growth performance, organ size, serum metabolites, and oxidative stress in postweaning gilts. J Anim Sci. 2011; 89: 3008-3015.

21. Marin DE, Pistol GC, Neagoe IV et al. Effects of zearalenone on oxidative stress and inflammation in weanling piglets. Food Chem Toxicol. 2013; 58: 408-415. 
22. Liu M, Gao R, Meng $Q$ et al. Toxic effects of maternal zearalenone exposure on intestinal oxidative stress, barrier function, immunological and morphological changes in rats. PLoS ONE. 2014; 9: e106412.

23. Jiang SZ, Yang ZB, Yang WR et al. Effect on hepatonephric organs, serum metabolites and oxidative stress in post-weaning piglets fed purified zearalenone-contaminated diets with or without Calibrin-Z. J Anim Physiol Anim Nutrit. 2012; 96: 1147-1156.

24. Hassen W, Ayed-Boussema I, Oscoz AA et al. The role of oxidative stress in zearalenone-mediated toxicity in Hep G2 cells: oxidative DNA damage, gluthatione depletion and stress proteins induction. Toxicology. 2007; 232: 294-302.

25. Abid-Essefi S, Ouanes Z, Hassen W et al. Cytotoxicity, inhibition of DNA and protein syntheses and oxidative damage in cultured cells exposed to zearalenone. Toxicol In Vitro. 2004; 18: 467-474

26. Venkataramana $M$, Chandra Nayaka $S$ et al. Zearalenone induced toxicity in SHSY-5Y cells: The role of oxidative stress evidenced by $\mathrm{N}$-acetyl cysteine. Food Chem Toxicol. 2014; 65: 335-342.

27. Abid-Essefi S, Zaied C, Bouaziz C et al. Protective effect of aqueous extract of Allium sativum against zearalenone toxicity mediated by oxidative stress. Experiment Toxicol Pathol. 2012; 64: 689-695.

28. Lee H, Kang C, Yoo YS et al. Cytotoxicity and the induction of the stress protein Hsp 70 in Chang liver cells in response to zearalenone-induced oxidative stress. Environ Toxicol Pharmacol. 2013; 36: 732-740.

29. Savard C, Nogues P, Boyer A et al. Prevention of deoxynivalenol- and zearalenone-associated oxidative stress does not restore MA-10 Leydig cell functions. Toxicology. 2016; 341-343: 17-27.

30. Li Z, Zhang $\mathrm{W}$, Chen $\mathrm{Y}$ et al. Impaired DNA double-strand break repair contributes to the age-associated rise of genomic instability in humans. Cell Death Diff. 2016; 23: 1765-1777.

31. Kang C, Lee H, Yoo YS et al. Evaluation of oxidative DNA damage using an alkaline single cell gel electrophoresis (SCGE) comet assay, and the protective effects of N-Acetylcysteine Amide on zearalenone-induced cytotoxicity in chang liver cells. Toxicol Res. 2013; 29: 43-52.

32. Xie $\mathrm{H}, \mathrm{Hu} \mathrm{J}$, Xiao $\mathrm{C}$ et al. Exploration of ZEA cytotoxicity to mouse endometrial stromal cells and RNA-seq analysis. J Biochem Mol Toxicol. 2017; 31(4).

33. Zhu L, Yuan $\mathrm{H}$, Guo $\mathrm{C}$ et al. Zearalenone induces apoptosis and necrosis in porcine granulosa cells via a caspase-3- and caspase-9-dependent mitochondrial signaling pathway. J Cell Physiol. 2012; 227: 1814-1820.

34. Duda M, Knet M, Tabarowski Z et al. Luteal macrophage conditioned medium affects steroidogenesis in porcine granulosa cells. Reprod Biol. 2011; 11: 117-134.

35. Li H, Handsaker B, Wysoker A et al. The sequence alignment/map format and SAMtools. Bioinformatics. 2009; 25: 2078-2089.

36. Kim D, Langmead B, Salzberg SL. HISAT: a fast spliced aligner with low memory requirements. Nat Methods. 2015; 12: 357-360.

37. Love MI, Huber W, Anders S. Moderated estimation of fold change and dispersion for RNA-seq data with DESeq2. Genome Biol. 2014; 15: 550.

38. Anders S, Pyl PT, Huber W. HTSeq--a Python framework to work with high-throughput sequencing data. Bioinformatics. 2014; 31: 166-169.

39. Yu G, Wang LG, Han $Y$ et al. clusterProfiler: an R package for comparing biological themes among gene clusters. OMICS. 2012; 16: 284-287.

40. Zhang $\mathrm{P}$, Chao $\mathrm{H}$, Sun $\mathrm{X}$ et al. Murine folliculogenesis in vitro is stage-specifically regulated by insulin via the Akt signaling pathway. Histochem Cell Biol. 2010; 134: 75-82.

41. Chao HH, Zhang XF, Chen B et al. Bisphenol A exposure modifies methylation of imprinted genes in mouse oocytes via the estrogen receptor signaling pathway. Histochem Cell Biol. 2012; 137: 249-259.

42. Winkler J, Kersten S, Meyer U et al. Diagnostic opportunities for evaluation of the exposure of dairy cows to the mycotoxins deoxynivalenol (DON) and zearalenone (ZEN): reliability of blood plasma, bile and follicular fluid as indicators. J Animal Physiol Anim Nutrit. 2015; 99: 847-855.

43. Cheraghi S, Razi M, Malekinejad H. Involvement of cyclin D1 and E2f1 in zearalenone-induced DNA damage in testis of rats. Toxicon. 2015; 106: 108-116.

44. Abbes S, Ouanes Z, Salah-Abbes JB et al. Preventive role of aluminosilicate clay against induction of micronuclei and chromosome aberrations in bone-marrow cells of Balb/c mice treated with Zearalenone. Mut Res. 2007; 631: 85-92.

45. Ayed-Boussema I, Ouanes $\mathrm{Z}$, Bacha $\mathrm{H}$ et al. Toxicities induced in cultured cells exposed to zearalenone: apoptosis or mutagenesis? J Biochem Mol Toxicol. 2007; 21: 136-144.

46. Ouanes Z, Abid S, Ayed I et al. Induction of micronuclei by zearalenone in Vero monkey kidney cells and in bone marrow cells of mice: protective effect of Vitamin E. Mut Res. 2003; 538: 63-70.

47. Ren Z, Deng H, Deng $\mathrm{Y}$ et al. Combined effects of deoxynivalenol and zearalenone on oxidative injury and apoptosis in porcine splenic lymphocytes in vitro. Experiment Toxicol Pathol. 2017; 69(8):612-617.

48. Yang D, Jiang T, Lin P et al. Apoptosis inducing factor gene depletion inhibits zearalenone-induced cell death in a goat Leydig cell line. Reprod Toxicol. 2017; 67: 129-139.

49. Cadet J, Ravanat JL, TavernaPorro $\mathrm{M}$ et al. Oxidatively generated complex DNA damage: tandem and clustered lesions. Cancer Lett. 2012; 327: 5-15.
50. Roos WP, Kaina B. DNA damage-induced cell death: from specific DNA lesions to the DNA damage response and apoptosis. Can Lett. 2013; 332: 237-248.

51. Zhou BB, Elledge SJ. The DNA damage response: putting checkpoints in perspective. Nature. 2000; 408: 433-439.

52. Jiang $\mathrm{H}$, Luo $\mathrm{S}, \mathrm{Li} \mathrm{H}$. Cdk5 activator-binding protein $\mathrm{C} 53$ regulates apoptosis induced by genotoxic stress via modulating the G2/M DNA damage checkpoint. J Biol Chem. 2005; 280: 20651-20659.

53. Gorgoulis VG, Vassiliou LV, Karakaidos P et al. Activation of the DNA damage checkpoint and genomic instability in human precancerous lesions. Nature. 2005; 434: 907-913.

54. Lopes M, Cotta-Ramusino C, Pellicioli A et al. The DNA replication checkpoint response stabilizes stalled replication forks. Nature. 2001; 412: 557-561.

55. Ibrahim B. Spindle assembly checkpoint is sufficient for complete Cdc20 sequestering in mitotic control. Comp Struct Biotechnol J. 2015; 13: 320-328.

56. Dery U, Coulombe $Y$, Rodrigue A et al. A glycine-arginine domain in control of the human MRE11 DNA repair protein. Mol Cell Biol. 2008; 28: 3058-3069.

57. Shibata A, Barton O, Noon AT et al. Role of ATM and the damage response mediator proteins 53BP1 and MDC1 in the maintenance of $\mathrm{G}(2) / \mathrm{M}$ checkpoint arrest. Mol Cell Biol. 2010; 30: 3371-3383.

58. Zhao H, Piwnica-Worms H. ATR-mediated checkpoint pathways regulate phosphorylation and activation of human Chk1. Mol Cell Biol. 2001; 21: 4129-4139.

59. Iftode C, Daniely Y, Borowiec JA. Replication protein A (RPA): the eukaryotic SSB. Crit Rev Biochem Mol Biol. 1999; 34: 141-180.

60. Braun KA, Lao Y, He Z et al. Role of protein-protein interactions in the function of replication protein A (RPA): RPA modulates the activity of DNA polymerase alpha by multiple mechanisms. Biochemistry. 1997; 36: 8443-8454.

61. Fanning E, Klimovich V, Nager AR. A dynamic model for replication protein A (RPA) function in DNA processing pathways. Nucleic Acids Res. 2006; 34 : 4126-4137.

62. Binz SK, Sheehan AM, Wold MS. Replication protein A phosphorylation and the cellular response to DNA damage. DNA Repair. 2004; 3: 1015-1024.

63. Chiruvella KK, Sebastian R, Sharma S et al. Time-dependent predominance of nonhomologous DNA end-joining pathways during embryonic development in mice. J Mol Biol. 2012; 417: 197-211.

64. Scully R, Chen J, Plug A et al. Association of BRCA1 with Rad51 in mitotic and meiotic cells. Cell. 1997; 88: 265-275.

65. Svetlova MP, Solovjeva LV et al. Mechanism of elimination of phosphorylated histone $\mathrm{H} 2 \mathrm{AX}$ from chromatin after repair of DNA double-strand breaks. Mut Res. 2010; 685: 54-60.

66. Chapman JR, Taylor MR, Boulton SJ. Playing the end game: DNA double-strand break repair pathway choice. Mol Cell. 2012; 47: 497-510.

67. Shrivastav M, De Haro LP et al. Regulation of DNA double-strand break repair pathway choice. Cell Res. 2008; 18: 134-147.

68. Ha K, Ma C, Lin $\mathrm{H}$ et al. The anaphase promoting complex impacts repair choice by protecting ubiquitin signalling at DNA damage sites. Nat Comm. 2017; 8: 15751

69. Gajęcka M. The effect of low-dose experimental zearalenone intoxication on the immunoexpression of estrogen receptors in the ovaries of pre-pubertal bitches. Polish J Vet Sci. 2012;15(4):685-691. 